\title{
Geophysical assessment for vertical leachate migration profile and physicochemical study of groundwater around the Olusosun dumpsite Lagos, south-west Nigeria
}

\author{
Anthony Aduojo Ameloko ${ }^{1}$ Elijah Adebowole Ayolabi ${ }^{2}$
}

Received: 20 April 2016 / Accepted: 31 July 2018 / Published online: 13 August 2018

(c) The Author(s) 2018

\begin{abstract}
The study was aimed at assessing the vertical movement of leachate from 2001 through 2015, and groundwater physicochemical parameters analysis around the Olusosun dumpsite, through a time-lapse study.Tracking the leachate vertical migration profile was achieved through analysis of VES time-lapse data obtained from previous investigations on the dumpsite between 2001 and 2006, and 2D resistivity data acquired from this study in 2014 and 2015. Seventeen borehole and hand-dug well water samples were obtained randomly from 17 sampling locations around the dumpsite, first, in August 2014 (wet season) and then a repeat in December 2015 (dry season). The results of the VES data and 2D resistivity analysis showed that there is a constant and progressive increase in the depth of migration of the contaminants generated on this site into the subsurface environment over the years. It also showed that the contaminated zones are characterised by resistivity values ranging from 0.63 to $12.5 \Omega \mathrm{m}$, and a maximum depth of $120 \mathrm{~m}$ has been impacted by the contaminants. The results of the water sample analysis showed clear variations for the various elemental constituents analysed for. Most of the physicochemical parameters analysed fell within the World Health Organisation (WHO) and the Nigerian Standard for Drinking Water Quality (NSDWQ) standard limit. Comparing the wet and dry season results, there was generally an increase in the mean concentrations of TDS, EC, temperature, hardness, $\mathrm{Ca}^{2+}, \mathrm{Mg}^{2+}, \mathrm{K}^{+}, \mathrm{Na}^{+}, \mathrm{Cl}^{-}, \mathrm{NO}_{3}^{-}, \mathrm{Zn}, \mathrm{Cu}, \mathrm{Pb}$ and $\mathrm{Cr}$ from the dry season study, particularly the samples with close proximity to the dumpsite. On the other hand, there was reduction in the mean concentrations of $\mathrm{SO}_{4}^{2-}, \mathrm{PO}_{4}^{3-}, \mathrm{Fe}, \mathrm{pH}$, and $\mathrm{Ni}$ from the dry season study when compared with the wet season. This trend could be attributed to the fact that in the absence of rainfall during the dry season period, contaminant accumulation in groundwater continued undiluted due to continuous breakdown of the biodegradables units with time, and this led to the generally high concentration of the physicochemical properties during the dry season. The implication is that the water around the study area has lower quality in the drier season when compared to the quality of water during the wet season, and so water treatment should be given more priority during the dry season before consumption and usage for other domestic purposes to avoid waterborne diseases. Generally, the information obtained from the geophysical study will facilitate decisions on improving protection for groundwater resources around the study area.
\end{abstract}

Keywords Concentration $\cdot$ Physicochemical $\cdot$ Landfill $\cdot$ Wet season $\cdot$ Dry season

Anthony Aduojo Ameloko

tonyameloko@yahoo.com

1 Department of Petroleum Engineering, Covenant University, Ota, Nigeria

2 Department of Geosciences, University of Lagos, Lagos, Nigeria

\section{Introduction}

An integrated geophysical survey consisting of 2D electrical resistivity imaging, time-lapse vertical electrical sounding (VES) and seasonal physicochemical measurement of groundwater parameters was conducted at the dumpsite with the aim of assessing and investigating the vertical migration profile of leachate contamination over time. The impact of seasonal variation on the physicochemical properties of groundwater around the dumpsite was also to be examined. One of the greatest challenges associated with landfilling activities is 
that of pollution to the environment, and more challenging is how to determine the extent of environmental pollution to the surface and subsurface environment. When it rains on a landfill, water percolates through the cells and soils in the landfill. As this continues, the water dilutes the decomposed materials (organic and inorganic chemicals, metals, biological waste products of decomposition) on the site to form what we refer to as leachates, and it is typically acidic. In landfills without liners, there might be migration of different organic and inorganic chemical compounds to the unsaturated zone of the soil which may reach the saturated zone (Mondelli 2004). These contaminated liquids may leave the disposal site, enter the underlying groundwater system and make the groundwater unpotable. If this water is used, the health of users is put at risk (Soupios et al. 2007). Theoretically, the electrical resistivity method measures variation in subsurface resistivity when a current is driven into the earth. From the measurements on earth surface of the electrical potential and the current, it is usually possible to obtain information about the variation of subsurface resistivities. Usually the methods are not used to detect contamination directly, but rather, they reveal contamination through sharp variation in subsurface resistivities as a result of the presence of these contaminants.

Studies abound in the literature on groundwater contamination. Such work includes (Bably and Kumari 2000). They concluded that there is need to monitor water quality on regular basis. This is because the increase in concentration of trace metals in potable water will increase the threat to man's health and life. The variation of groundwater quality in an area is a function of physical and chemical parameters that are greatly influenced by geological formations and anthropogenic activities (Subramani et al. 2005). Recent studies around the Olusosun dumpsite revealed continuous degradation of the groundwater quality. According to Adeyi and Majolagbe (2014), almost all the groundwater collected around Olusosun dumpsite showed level of nitrate higher than that of WHO permissible limit of $10 \mathrm{mg} / \mathrm{L}$. This situation is of great health risk as nitrate pollution has been linked to myth and sometimes death. The groundwater vulnerability index analysis around the dumpsite showed values between 61.8 and 205, indicating good-poor-very poor class of water, and about sixty per cent of water collected around the dumpsite are unsafe for human consumption without further treatment (Abdulrafiu et al. 2016). The uncontrolled disposal of lead acid batteries and spent petroleum products probably caused relatively higher levels of $\mathrm{Pb}, \mathrm{Cu}$ and $\mathrm{Fe}$ found in groundwater around the study area (Oyeku and Eludoyin 2010). Also, statistical analyses of physical parameters determined in situ on groundwater from the work of Ayolabi et al. (2014) around the dumpsite showed elevated concentrations of total dissolved solid, electrical conductivity, temperature and high acidic content. They concluded that the high level of pollution has been accelerated by the weak protective capacity of the thick laterite delineated within the study area. The present study therefore attempts to investigate the vertical migration history of the leachates within the subsurface between 2001 and 2015, and assess the groundwater physicochemical parameters around the Olusosun dumpsite through a time-lapse study.

\section{Field description}

The Olusosun dumpsite is a controlled dumpsite located at Ojota, Lagos, within longitude $03.372 \mathrm{E}$ to $03.374 \mathrm{E}$ and latitude $06.588 \mathrm{~N}$ to $06.595 \mathrm{~N}$. It is the largest government-owned dump facility in Nigeria, and it is managed by the Lagos Waste Management Authority (LAWMA). It is about 18 meters deep and covers close to 42 hectares of land. Olusosun refuse dump was established in 1991 with a lifespan of 35 years. The dump is surrounded by Oregun industrial layout, Olusosun residential compound, Shangisah residential areas and commercial neighbourhood (Fig. 2). It receives an average of 1.2 million tons of assorted wastes annually and is presently serving as a pilot project for biogas production in Nigeria (LAWMA 2004).

\section{Geological and hydrogeology of the study area}

The study area is located within the Eastern Dahomey Basin. The basin is very extensive and consists of Cretaceous Tertiary sedimentary sequence that thin out on the east and are partially cut off from the sediment of the Niger Delta Basin by the Okitipupa ridge. In general, rocky outcrops are poor due to the thick vegetation and soil cover. The knowledge of the geology of this basin had been improved through the availability of boreholes and recent road cuts. Major lithological sequences associated with the Basin are Abeokuta Formations (Ise, Afowo and Araromi Formations), and Ewekoro, Akinbo, Oshoshun, Ilaro and Benin Formations (Fig. 1). The lithology is composed of loose sediment ranging from silt, clay and fine to coarse grained sand, called coastal plain sand. The exposed surface consists of poorly sorted sands with lenses of clays. The sands are in part cross-bedded and show transitional to continental characteristics (Agagu 1985; Enu 1990; Jones and Hockey 1964; Nton 2001; Omatsola and Adegoke 1981). Basically, there are four major aquiferous units that are being tapped for the purpose of water supply in the Lagos metropolis: The first aquifer extends from the ground level to roughly $12 \mathrm{~m}$ below the ground. It consists of alternation layers of clay and sand. This aquifer is prone to contamination from surficial activities because of its limited depth. The second aquifer is encountered between 20 and $100 \mathrm{~m}$ below the sea level, and it can be found around Ikeja and Ojota axis. This aquifer is of greater importance for water supply purposes throughout Lagos metropolis (Jones 

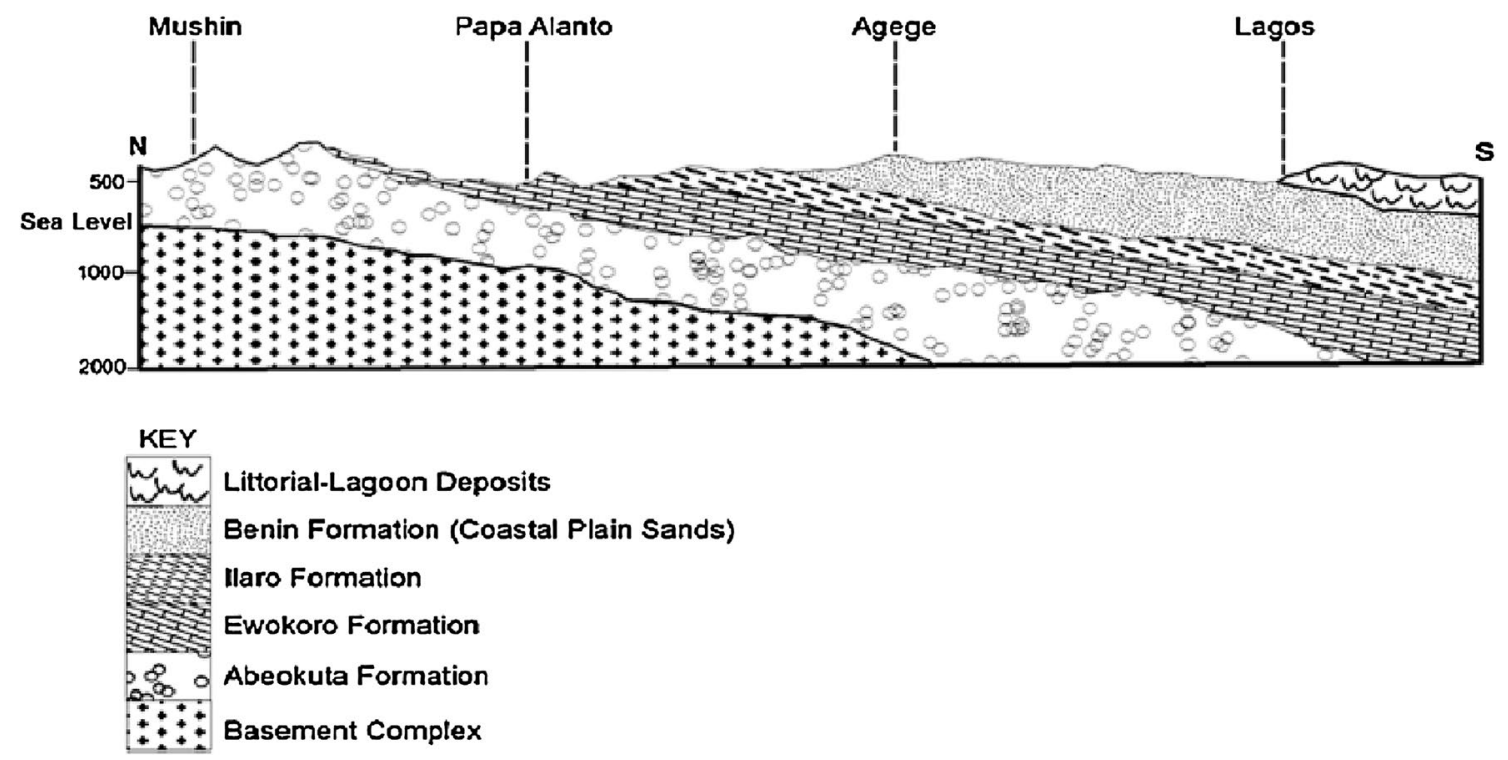

Fig. 1 Geological section showing the major geological formations in the Lagos area. (Reproduced with permission from Jones and Hockey 1964)

and Hockey 1964). The third aquifer is encountered in the central part of Lagos at a depth ranging from 130 to $160 \mathrm{~m}$ below the sea level. The fourth aquifer is located at an elevation of approximately $450 \mathrm{~m}$ below the sea level. It is separated from the third aquifer by a rather thick layer of shale of the Ewekoro formation. Only few boreholes tap water from this aquifer (Jones and Hockey 1964).

\section{Materials and methods}

\section{D resistivity imaging}

Thoroughfare and tipping of waste by LAWMA trucks restricted the number of profiles occupied on the dumpsite. The electrical resistivity tomography surveys were carried out with a digital readout Super Sting R8 Earth Resistivity/IP meter along the profiles (Fig. 2), using a multi-electrode system (84 electrodes). The 2D resistivity data were collected along the profiles using pole-dipole array in May 2014 and a time-lapse survey in May 2015. The total profile length of $420 \mathrm{~m}$ was occupied on the dumpsite, and $336 \mathrm{~m}$ on the control outside of the dumpsite. The choice of the electrode arrays was to enable maximum depth of investigation, good horizontal resolution and data coverage (Loke and Barker 1996). The 2D data were processed and inverted using the Earth Imager inversion algorithm. The algorithm calculates the apparent resistivity values using forward modelling subroutine (AGI 2003). It generates the inverted resistivity-depth image for each profile line based on an iterative smoothness constrained least-squares inversion algorithm (Loke and Barker 1996). Generally, the programme automatically creates a $2 \mathrm{D}$ model by dividing the subsurface into rectangular blocks (Loke and Barker 1996), and the resistivity of the model blocks was iteratively adjusted to reduce the difference between the measured and the calculated apparent resistivity values. (A measure of this difference is given by the root-mean-squared (RMS) error). Available time-lapse VES resistivity data sets obtained by previous workers from the dumpsite were analysed and interpreted using curve-matching technique to obtain the resistivity and thickness of each of the layers delineated. This was then used as a starting model for a more quantitative computer iterative method (WinRESIST) which then gives the true thickness and resistivity of the layers delineated. The aim was to assess the trend of leachate migration within the subsurface over the years.

\section{Physicochemical analysis of water samples}

Seventeen borehole and hand-dug well water samples were obtained randomly from 17 sampling locations around the dumpsite, first, in August 2014 during the wet season and then a repeat experiment in December 2015 during the dry season (Fig. 2). The samples were collected in a 7.5-L plastic bottles and were well stored after which they were transferred to chemistry laboratory of University of Lagos for chemical analysis after standard methods (APHA 2005). The heavy metals analysed for using the atomic absorption spectrophotometer (AAS) include $\mathrm{Fe}, \mathrm{Cu}, \mathrm{Ni}, \mathrm{Pb}, \mathrm{Zn}, \mathrm{Mn}$ and $\mathrm{Cr}$. Other elements analysed for include $\mathrm{Mg}^{2+}, \mathrm{Na}^{+}, \mathrm{K}^{+}, \mathrm{Ca}^{2+}$ and anions such as $\mathrm{PO}_{4}^{3-}, \mathrm{SO}_{4}^{2-}, \mathrm{NO}_{3}^{-}$and $\mathrm{Cl}^{-}$. The physical properties of the water samples tested for are total dissolved solid (TDS), $\mathrm{pH}$ values, temperatures, hardness and electrical conductivity (EC). The

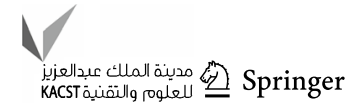




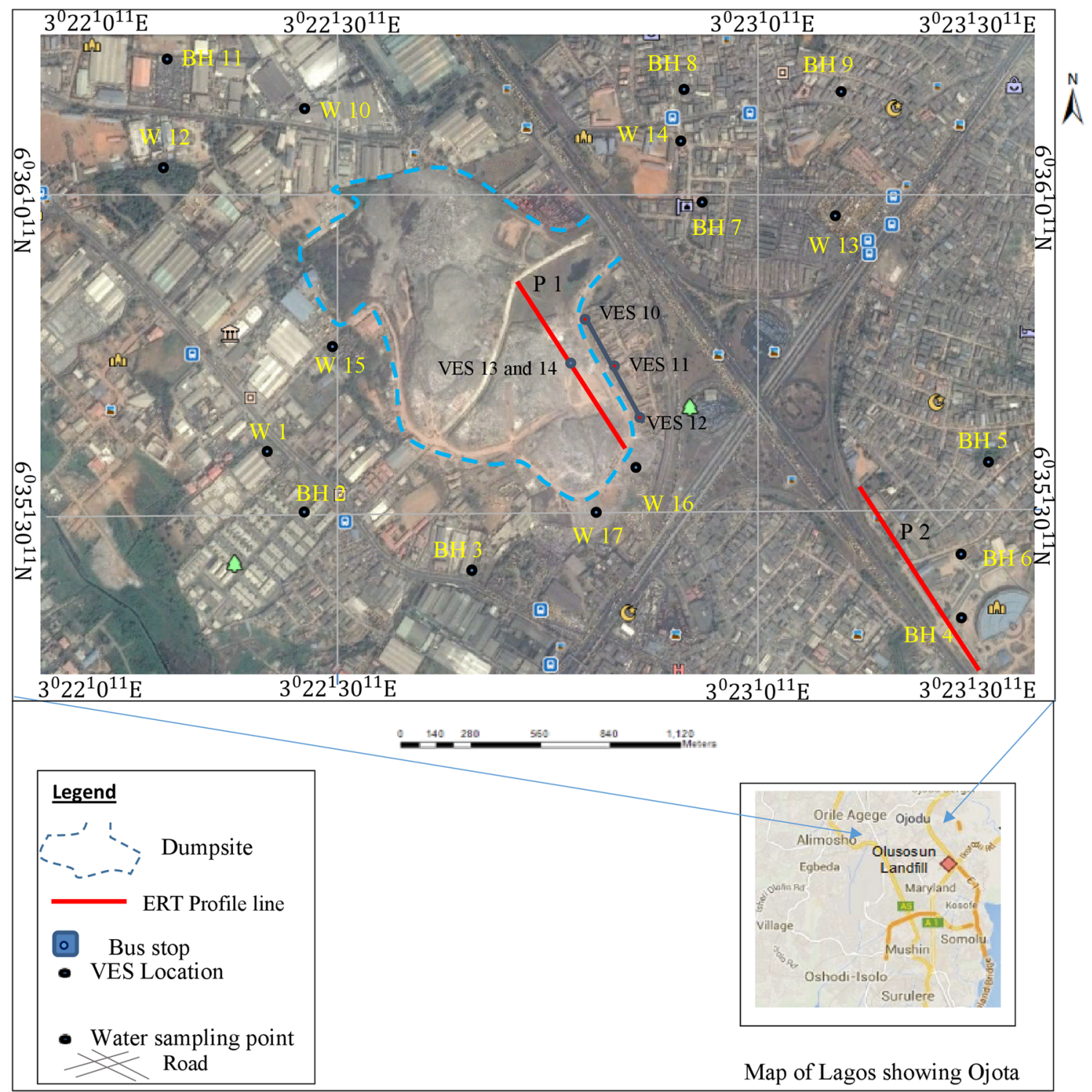

Fig. 2 Data acquisition map of the study area

samples were collected in a bowl, and these properties were measured in situ with the aid of a portable EC/TDS meter. Global Positioning System (Garmin GPS Channel 76 model) was used to take the coordinates of the sampling locations.

\section{Results and discussion}

\section{VES and 2D resistivity analysis}

The results of the time-lapse VES data acquired in 2001, 2002 and 2006 by previous investigations along profile 1 on the Olusosun dumpsite (Fig. 2) show that there is continuous increase in the depth of migration of the contaminants generated on the dumpsite into the subsurface environment over the years. For instance, Fig. 3a shows the sounding curve for the data acquired in 2001. The maximum depth of penetration of the leachate was $30 \mathrm{~m}$ in 2001 . The depth of migration increased to about $34 \mathrm{~m}$ in 2002 (Fig. 3b), and in 2006, the VES result along the same point shows a maximum depth of about $71 \mathrm{~m}$ (Fig. 3c). The 2D ERT result obtained from this study in 2014 along profile 1 revealed a maximum depth of penetration of $106 \mathrm{~m}$ by the leachate and about $120 \mathrm{~m}$ in 2015 (Fig. 4). Information from borehole log obtained around the area (Fig. 4c) indicates that the shallow aquifers underlying the dumpsite have been invaded by the contaminants from the decomposed waste materials. Figure 5 shows the vertical migration profile of the leachate contaminant on the dumpsite from 2001 through 2015. Based on this information unravelled by this study, it 
(a)

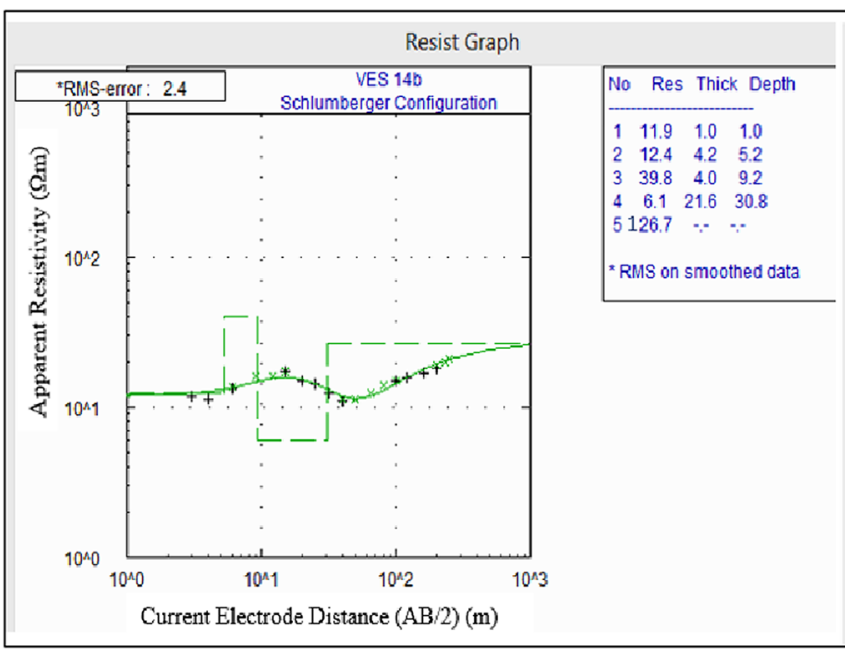

(b)

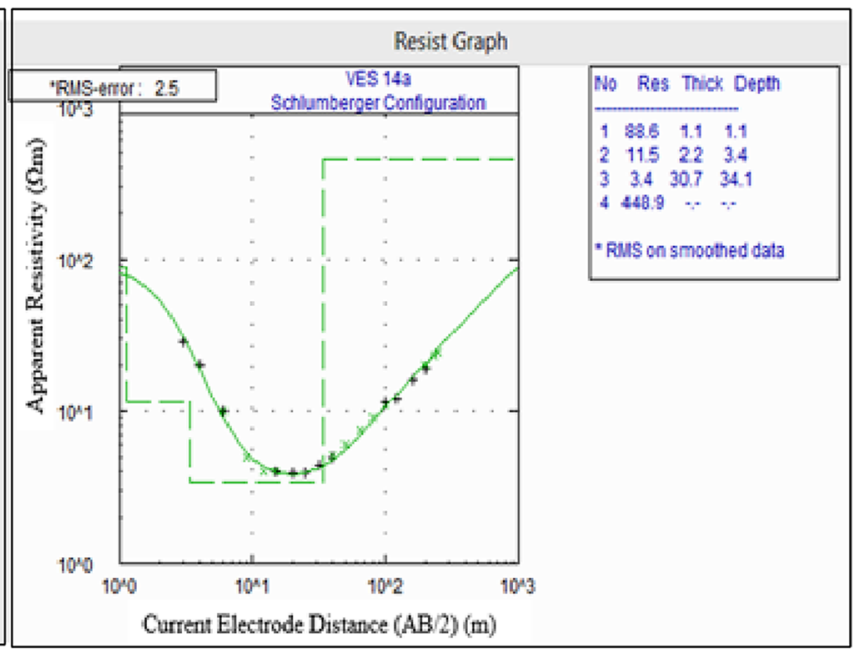

(c)

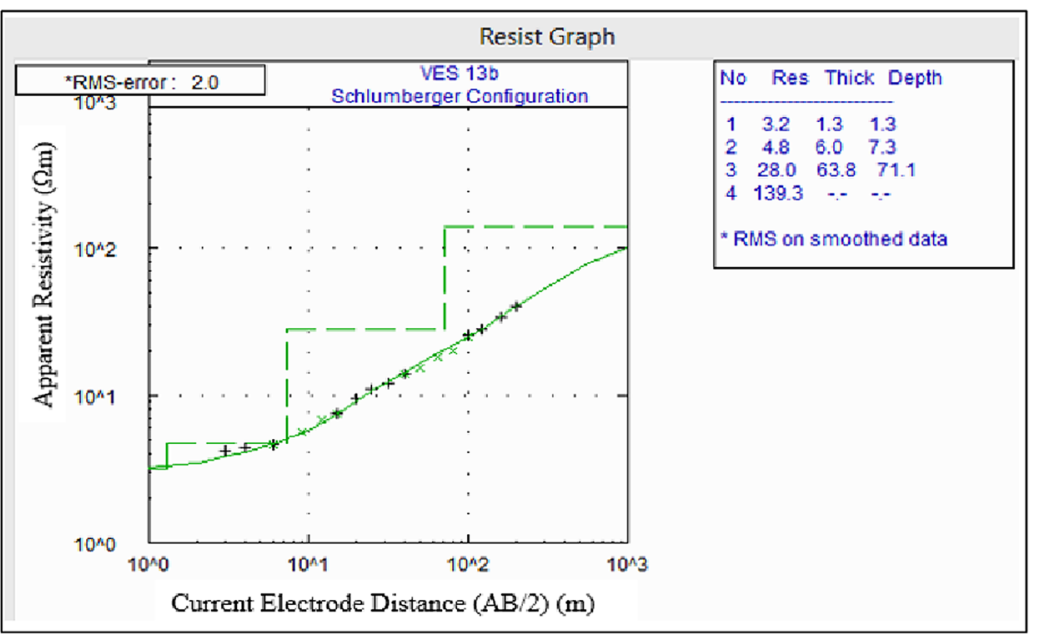

Fig. 3 VES sounding curves obtained along traverse 1 on the dumpsite in a 2001 b 2002 and c 2006

(a)

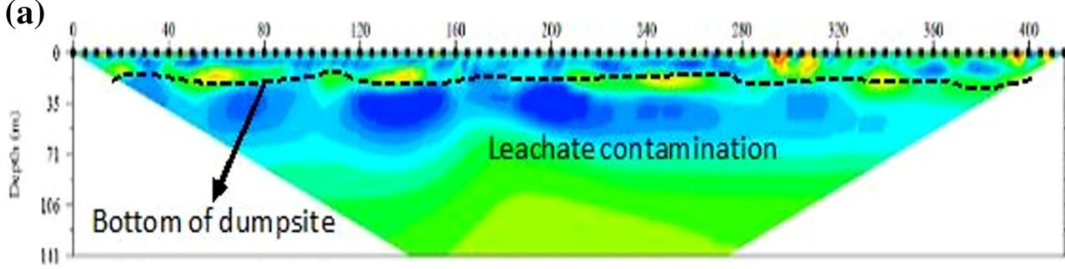

(b)

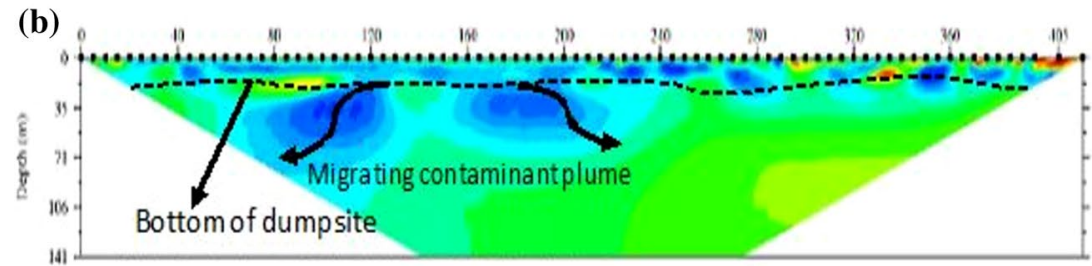

(c) Borehole
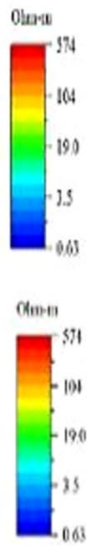

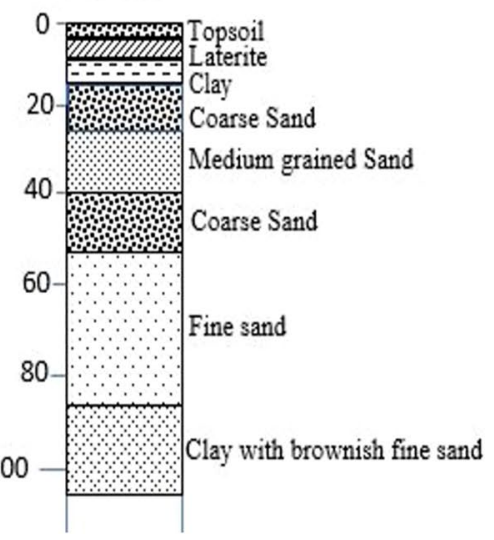

Fig. 4 Resistivity models obtained from the independent inversion of pole-dipole resistivity data measured in December 2014 (a) and poledipole resistivity data measured in December 2015 (b) 
Fig. 5 Geoelectric section around profile 1 showing progressive increase in the depth of migration of leachate from 2001 through 2015 on the Olusosun dumpsite

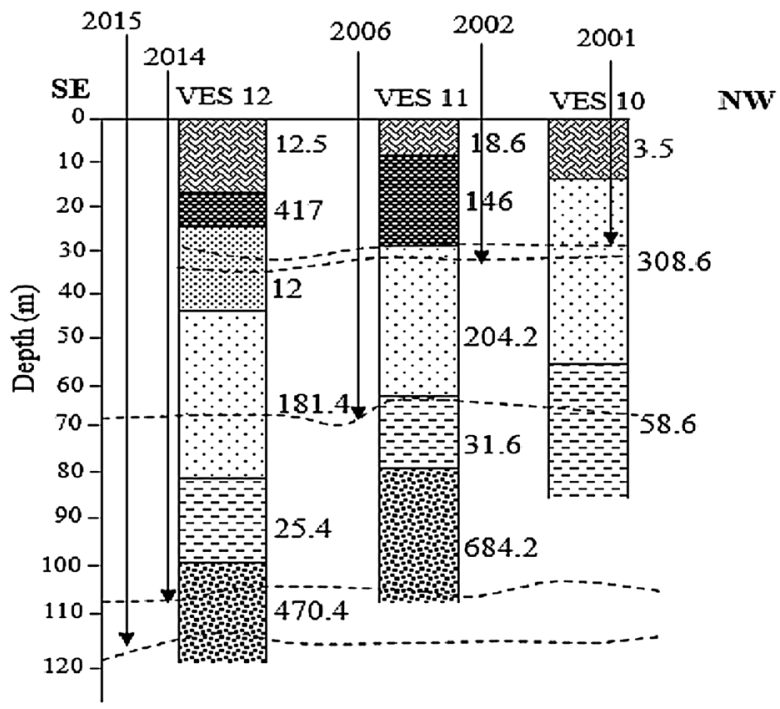

is recommended that in exploring groundwater around this area, deeper aquifers should be targeted in order to access clean water. Previous study of the protective capacity of the overburden at the Olusosun area revealed that the longitudinal conductance of the overburden materials ranges between 0.0006 and 0.0055 . This generally shows that the overburden material is of weak protective capacity and that this may also have been largely responsible for the easy percolation of leachate to the groundwater aquifer and subsequent pollution of same (Ayolabi 2005). The implication of this trend is that if nothing is done in the nearest future to remediate the trend, the entire hydrogeologic units around the communities could be polluted as a result of the continuous vertical and lateral migration of leachates from the site, and it will be difficult to get clean water from boreholes around the area. Generally, information obtained from this study will facilitate decisions on improving protection for groundwater resources around the area.

The 2D resistivity pole-dipole models obtained as control along profile 2 outside of the dumpsite is shown in Fig. 6 . They were obtained about $800 \mathrm{~m}$ away, along the northwest and south-east direction. The low-resistivity region from $288 \mathrm{~m}$ to the $320 \mathrm{~m}$ mark on the surface along the sections coincides with a surface wastewater body (industrial discharge) flowing from source most likely to be from a nearby company/industry. This flowing surface water body which may be percolating constantly into the subsurface sandy hydrogeologic unit may be responsible for this

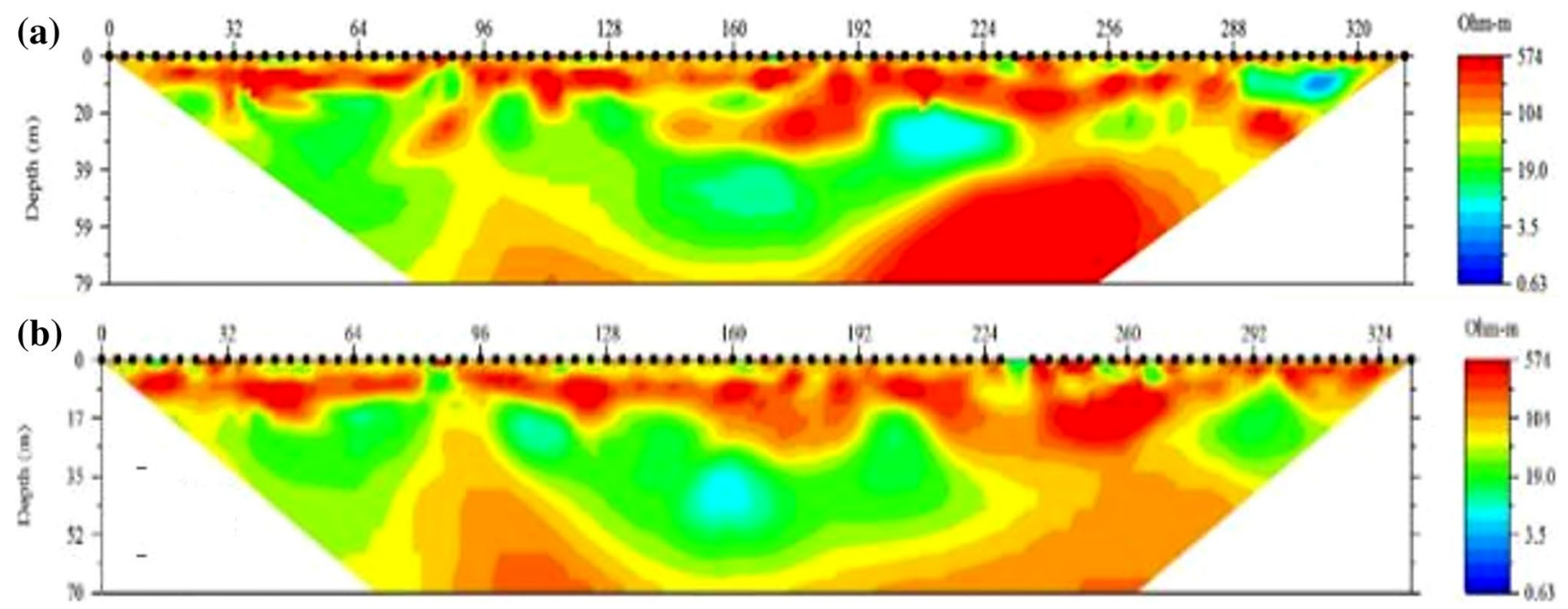

Fig. 6 Resistivity models obtained from the independent inversion of pole-dipole resistivity data measured in May 2014 (a) and December 2015 (b) 
low-resistivity anomaly seen towards the end of the models. The relatively high resistivity values associated with this control models and that of the values associated with the measurements on the dumpsites validates the interpretation of contamination on the dumpsites.

\section{Physicochemical}

\section{Total dissolved solid (TDS)}

The seasonal variation of the measured TDS versus WHO (2007) minimum standard (500 mg/L) for drinking water quality across the sampling locations is presented in Table 1. From the physical properties of water samples obtained around this site, the total dissolved solute (TDS) values obtained from the boreholes ranges between $40-1200 \mathrm{mg} / \mathrm{L}$ in 2014 and $53-2021 \mathrm{mg} / \mathrm{L}$ in 2015. Well locations BH 3, BH 4, W 16 and W 17 were high above the maximum permissible levels proposed by WHO (2007) which is $500 \mathrm{mg} / \mathrm{L}$ (Fig. 6). The mean concentration of TDS at the site increased from $308.41 \mathrm{mg} / \mathrm{L}$ in 2014 to $369.82 \mathrm{mg} / \mathrm{L}$ in 2015 , with difference of 61.41 $(19.91 \%)$ and TDS exceeded the prescribed Standard limits of $(500 \mathrm{mg} / \mathrm{L})$ set by WHO (2007) in about $17.6 \%$ and 29.4\% each in wet and dry seasons, respectively (Fig. 7). The high concentration of TDS at these points may be an indication of the presence of inorganic salts (such as calcium, magnesium, potassium, sodium, bicarbonates, chlorides, and sulphates). Comparing the wet and dry results, there is generally an increase in concentration of TDS in the dry season study. This may be attributed to the fact that the soil is less saturated with water during the dry month and the leachate concentration increases due to breaking down of much of the biodegradable, while lower concentration during the rainy season could be as a result of the leachate dilution during heavy rains, and hence they become less concentrated. The spatial distribution map of TDS obtained in 2014 show a general increase towards the south-eastern part of the study area (Fig. 8). This region is likely to be the groundwater flow direction since contaminants are usually mobilised in the direction of groundwater flow.

\section{Electrical conductivity (EC)}

The electrical conductivity (EC) is a reflection of the degree of dissolved matters in water. Chemically pure water has a very low EC. The EC in the study area ranges from 117 to $2589 \mu \mathrm{S} / \mathrm{cm}$ in the wet season and $107-4043 \mu \mathrm{S} / \mathrm{cm}$ in dry season with increased mean concentration from $643.18 \mu \mathrm{S} / \mathrm{cm}$ in 2014 to $944.12 \mu \mathrm{S} / \mathrm{cm}$ in 2015 , and difference of $300.94 \mu \mathrm{S} / \mathrm{cm}$ (46.8\%). Results of the seasonal variations in the concentration of EC versus WHO (2007) standard for drinking water quality across the sampling locations revealed that, EC exceeded the standard limit $(1000 \mu \mathrm{S} / \mathrm{cm})$ for drinking water quality in $23.5 \%$ of the locations for wet season and about $29.4 \%$ in dry season (Fig. 9). The EC concentration also shows a strong correlation with the TDS. The results also show a general increase in the EC concentration in the dry season when compared with the wet season. The spatial distribution map of EC obtained in 2014 also correlates strongly with that of TDS as EC generally increase towards the southeastern part of the study area (Fig. 10).

\section{Hardness}

Hardness is normally expressed as the total concentration of $\mathrm{Ca}^{2+}$ and $\mathrm{Mg}^{2+}$ in $\mathrm{mg} / \mathrm{L}$, equivalent $\mathrm{CaCO}_{3}$. Hardness ranged from 45 to $167 \mathrm{mg} / \mathrm{L}$ in the wet season and 75 to $367 \mathrm{mg} / \mathrm{L}$ in December 2015. Strong linear relationship exists between the observed hardness of water and the TDS and EC concentration from all the locations. About $88.2 \%$ and $70.6 \%$ of the measured hardness values are below the minimum requirement $(150 \mathrm{mg} / \mathrm{L})$ for drinking water in wet and dry seasons, respectively (Table 1). Mean concentration of hardness increased from $89.23 \mathrm{mg} / \mathrm{L}$ in 2014 to $136.29 \mathrm{mg} / \mathrm{L}$ in 2015, with difference of $47.06 \mathrm{mg} / \mathrm{L}$ (52.74\%). Only W1, $\mathrm{BH} 3, \mathrm{BH} 4, \mathrm{~W} 16$, and $\mathrm{W} 17$ of the values are above the standard limit of $150 \mathrm{mg} / \mathrm{L}$. Comparing the wet and dry results, there is a corresponding increase in concentration of hardness when compared with TDS and EC values obtained in the dry season study.

\section{$\mathrm{pH}$}

$\mathrm{pH}$ is one of the factors which influence the fate and the transport of contaminants in the environment. Increasing acidity (low $\mathrm{pH}$ ) can cause some metals and nutrients to dissolve in water thereby releasing toxic elements that may pollute groundwater. Conversely, decreasing acidity (high $\mathrm{pH})$ can cause certain nutrients to become insoluble and thereby unavailable for plant growth. When the soil $\mathrm{pH}$ is greater than 7.5, calcium can tie up phosphorus, making it less available to plants (Lake 2000). Depending on other factors such as solubility, contaminants leaching and groundwater contamination is enhanced in the low-pH wastes in the Olusosun landfill. Most jurisdictions including USEPA (2013) and NSDWQ (2007) allow the pH of water to fall between 6.5 and 8.5. The seasonal variation of the measured $\mathrm{pH}$ versus WHO (2007) minimum standard (6.5) for drinking water quality across the sampling locations is presented in Table 1. About $29.4 \%$ and $82.4 \%$ of the measured $\mathrm{pH}$ values were below the minimum requirement in wet and dry seasons, respectively. The mean value of $\mathrm{pH}$ reduced

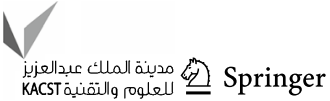


Table 1 Seasonal paired-sample statistics of groundwater physical parameters around Olusosun landfill

\begin{tabular}{|c|c|c|c|c|c|c|c|}
\hline Sample & Location & Coordinate & $\mathrm{pH}$ & Temp $\left({ }^{\circ} \mathrm{C}\right)$ & $\mathrm{EC}(\mu \mathrm{S} / \mathrm{cm})$ & TDS (ppm/mg/L) & Hardness $(\mathrm{mg} / \mathrm{L})$ \\
\hline \multirow[t]{2}{*}{ W 1} & \multirow[t]{2}{*}{ Mashalachi street } & $06^{\circ} 35^{\prime} 27.69^{\prime \prime} \mathrm{N}$ & 6.52 & 27.4 & 1024 & 496 & 125.0 \\
\hline & & $003^{\circ} 22^{\prime} 19.48^{\prime \prime} \mathrm{E}$ & 6.71 & 30.7 & 1079 & 539 & 200.0 \\
\hline \multirow[t]{2}{*}{ BH 2} & \multirow[t]{2}{*}{ Anisere Close } & $06^{\circ} 35^{\prime} 23.13^{\prime \prime} \mathrm{N}$ & 6.96 & 26.4 & 147 & 73 & 65.0 \\
\hline & & $003^{\circ} 22^{\prime} 21.75^{\prime \prime} \mathrm{E}$ & 6.67 & 30.7 & 575 & 257 & 80.0 \\
\hline \multirow[t]{2}{*}{ BH 3} & \multirow[t]{2}{*}{ Kudirat Abiola Way } & $06^{\circ} 35^{\prime} 23.86^{\prime \prime} \mathrm{N}$ & 6.21 & 27.3 & 1950 & 992 & 145.0 \\
\hline & & $003^{\circ} 22^{\prime} 30.67^{\prime \prime} \mathrm{E}$ & 7.06 & 30.6 & 4043 & 2021 & 246.0 \\
\hline \multirow[t]{2}{*}{ BH 4} & \multirow[t]{2}{*}{ Ayinde Street } & $06^{\circ} 35^{\prime} 26.12^{\prime \prime} \mathrm{N}$ & 6.79 & 27.0 & 139 & 48 & 70.0 \\
\hline & & $003^{\circ} 23^{\prime} 26.79^{\prime \prime} \mathrm{E}$ & 6.46 & 30.7 & 1158 & 579 & 160.0 \\
\hline \multirow[t]{2}{*}{ BH 5} & \multirow[t]{2}{*}{ Niyi Ogunleye Street } & $06^{\circ} 35^{\prime} 19.26^{\prime \prime} \mathrm{N}$ & 6.83 & 27.4 & 137 & 50 & 90.0 \\
\hline & & $003^{\circ} 23^{\prime} 24.76^{\prime \prime} \mathrm{E}$ & 6.14 & 30.4 & 646 & 321 & 95.0 \\
\hline \multirow[t]{2}{*}{ BH 6} & \multirow[t]{2}{*}{ By Chinese Village } & $06^{\circ} 35^{\prime} 17.74^{\prime \prime} \mathrm{N}$ & 6.81 & 26.2 & 325 & 161 & 60.0 \\
\hline & & $003^{\circ} 23^{\prime} 18.73^{\prime \prime} \mathrm{E}$ & 6.10 & 30.8 & 634 & 319 & 95.0 \\
\hline \multirow[t]{2}{*}{ BH 7} & \multirow[t]{2}{*}{ By Jehovah Witness } & $06^{\circ} 35^{\prime} 59.49^{\prime \prime} \mathrm{N}$ & 6.85 & 26.7 & 117 & 40 & 60.0 \\
\hline & & $003^{\circ} 22^{\prime} 54.21^{\prime \prime} \mathrm{E}$ & 4.08 & 30.4 & 727 & 361 & 100.0 \\
\hline \multirow[t]{2}{*}{ BH 8} & \multirow[t]{2}{*}{ Ikosi Street } & $06^{\circ} 36^{\prime} 08.46^{\prime \prime} \mathrm{N}$ & 3.83 & 28.1 & 607 & 304 & 75.0 \\
\hline & & $003^{\circ} 22^{\prime} 56.23^{\prime \prime} \mathrm{E}$ & 4.49 & 30.6 & 219 & 110 & 75.0 \\
\hline \multirow[t]{2}{*}{ BH 9} & \multirow[t]{2}{*}{ Ogunmoyo Street } & $06^{\circ} 36^{\prime} 08.39^{\prime \prime} \mathrm{N}$ & 6.67 & 28.0 & 140 & 75 & 80.0 \\
\hline & & $003^{\circ} 22^{\prime} 47.71^{\prime \prime} \mathrm{E}$ & 4.29 & 30.3 & 521 & 257 & 125.0 \\
\hline \multirow[t]{2}{*}{ W 10} & \multirow[t]{2}{*}{ Adeniyi Street } & $06^{\circ} 36^{\prime} 04.19^{\prime \prime} \mathrm{N}$ & 4.02 & 27.1 & 397 & 193 & 45.0 \\
\hline & & $003^{\circ} 22^{\prime} 04.16^{\prime \prime} \mathrm{E}$ & 4.45 & 30.5 & 306 & 154 & 105.0 \\
\hline \multirow[t]{2}{*}{ BH 11} & \multirow[t]{2}{*}{ Bankole Street } & $06^{\circ} 36^{\prime} 07.44^{\prime \prime} \mathrm{N}$ & 4.00 & 26.9 & 790 & 325 & 95.0 \\
\hline & & $003^{\circ} 21^{\prime} 58.17^{\prime \prime} \mathrm{E}$ & 5.76 & 30.6 & 107 & 53 & 75.0 \\
\hline \multirow[t]{2}{*}{ W 12} & Bankole Street & $06^{\circ} 36^{\prime} 05.23^{\prime \prime} \mathrm{N}$ & 4.31 & 27.8 & 366 & 187 & 70.0 \\
\hline & & $003^{\circ} 21^{\prime} 53.09^{\prime \prime} \mathrm{E}$ & 4.61 & 30.4 & 353 & 176 & 85.0 \\
\hline W 13 & Ikosi High School & $06^{\circ} 35^{\prime} 56.92^{\prime \prime} \mathrm{N}$ & 6.21 & 28 & 160 & 83 & 68 \\
\hline & & $003^{\circ} 22^{\prime} 47.30^{\prime \prime} \mathrm{E}$ & 4.67 & 28.5 & 178 & 90 & 75 \\
\hline W 14 & Anglican Church & $06^{\circ} 35^{\prime} 58.11^{\prime \prime} \mathrm{N}$ & 6.77 & 27.0 & 127 & 56 & 64 \\
\hline & & $003^{\circ} 22^{\prime} 45.44^{\prime \prime} \mathrm{E}$ & 5.42 & 28.0 & 170 & 80 & 80.0 \\
\hline W 15 & Supreme Road & $06^{\circ} 35^{\prime} 42.03^{\prime \prime} \mathrm{N}$ & 5.84 & 29.3 & 482 & 222 & 82 \\
\hline & & $003^{\circ} 22^{\prime} 23.20^{\prime \prime} \mathrm{E}$ & 4.80 & 30.0 & 400 & 220 & 98 \\
\hline W 16 & Ojota Motor Park & $06^{\circ} 35^{\prime} 31.47^{\prime \prime} \mathrm{N}$ & 6.79 & 32.4 & 2589 & 1200 & 167 \\
\hline & & $003^{\circ} 22^{\prime} 50.05^{\prime \prime} \mathrm{E}$ & 4.21 & 30.7 & 3200 & 1500 & 367 \\
\hline W 17 & Agofure Motors & $06^{\circ} 35^{\prime} 27.95^{\prime \prime} \mathrm{N}$ & 6.83 & 33.6 & 1437 & 738 & 156 \\
\hline & & $003^{\circ} 22^{\prime} 48.84^{\prime \prime} \mathrm{E}$ & 5.20 & 31.7 & 1734 & 950 & 256 \\
\hline Mean & & & 6.01 & & 643.18 & 308.41 & 89.23 \\
\hline & & & 5.36 & & 944.12 & 469.82 & 136.29 \\
\hline Range & & & $3.83-6.69$ & & 117-2589 & $40-1200$ & 45-167 \\
\hline & & & $4.08-7.06$ & & $107-4043$ & $53-2021$ & $75-367$ \\
\hline SD & & & 1.17 & & 722.1 & 350.94 & 36.53 \\
\hline & & & 1.00 & & 1100.9 & 542.56 & 83.57 \\
\hline Coef. of & & & 19.47 & & 112.3 & 92.25 & 40.93 \\
\hline $\begin{array}{l}\text { variation } \\
(\%)\end{array}$ & & & 18.65 & & 116.6 & 115.5 & 61.31 \\
\hline & WHO/SON standard & & $6.5-8.5$ & - & 1000 & 500 & 150 \\
\hline
\end{tabular}

Bold: August 2014 results (wet season); italic: December 2015 results (dry season) $B H$ borehole, $W$ well 
Fig. 7 Seasonal variations in TDS concentration of water sample versus WHO standard around the Olusosun dumpsite
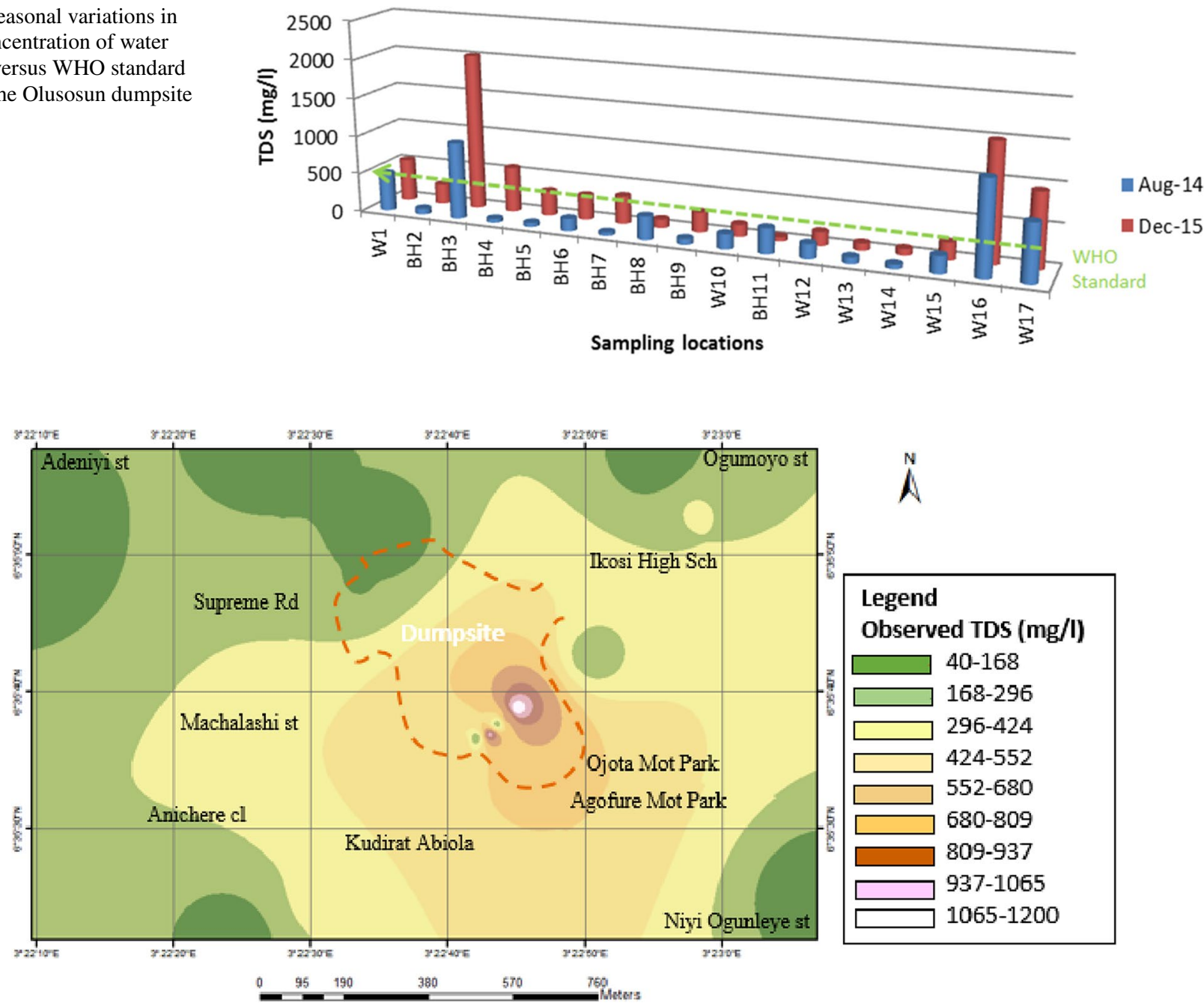

Fig. 8 Spatial distribution of total dissolved solid within the study area

Fig. 9 Seasonal variations in EC concentration of water samples versus WHO standard around the Olusosun dumpsite

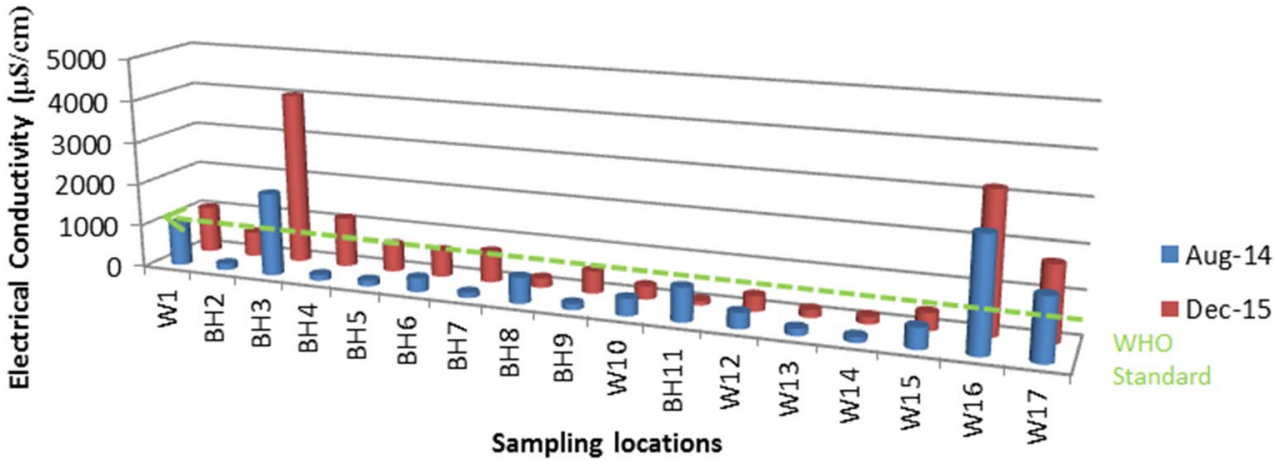

from 6.01 to 5.36 with interval difference of 0.65 (12.13\%), and values ranging from 3.83 to 6.69 in August 2014 and 4.08-7.06 in December 2015. There is $64.7 \%$ reduction in $\mathrm{pH}$ values obtained around the site during the dry season study.

\section{Metal concentration in groundwater samples}

Table 2 provides the Seasonal Paired Samples Statistics of some of the elements and anion contents of water samples obtained around the Olusosun dumpsite. Sodium, calcium, 


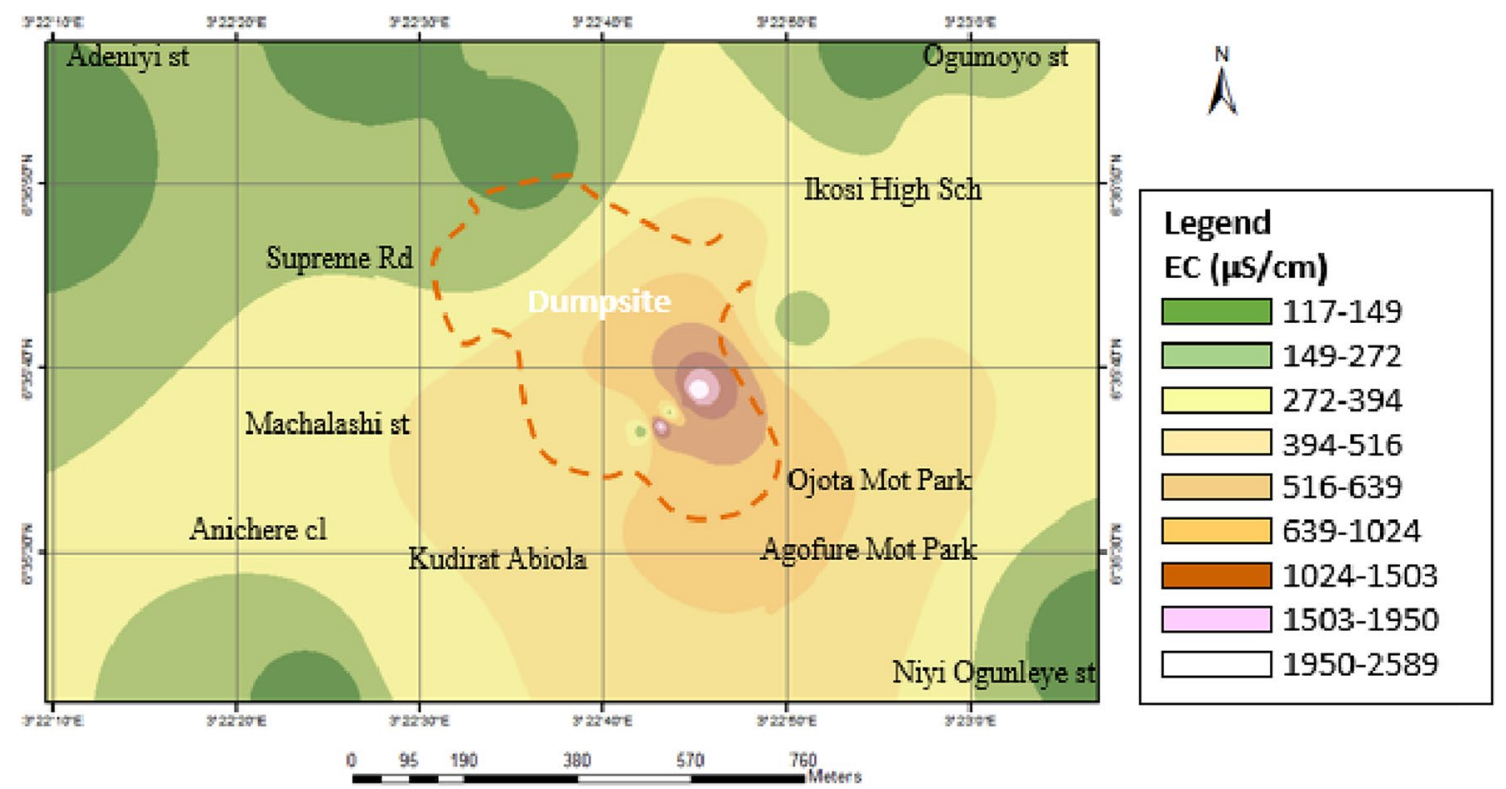

Fig. 10 Spatial distribution of electrical conductivity within the study area

potassium and magnesium are of nutritional importance to life, so they are referred to as essential metals. They help in various metabolic activities in the human body system. Calcium and magnesium concentrations in groundwater samples from all the sampling points have mean values of $34.85 \mathrm{mg} / \mathrm{L}$ and $11.61 \mathrm{mg} / \mathrm{L}$ in 2014 and $47.72 \mathrm{mg} / \mathrm{L}$ and $19.17 \mathrm{mg} / \mathrm{L}$ in 2015 , respectively. Calcium and magnesium do not pose potential adverse health effects in drinking water. The presence of both ions in water increases its hardness, which results in the use of more soaps than what is necessary for bathing and washing. Both calcium and magnesium are beneficial to human health, and past epidemiological studies have supported the hypothesis that extra magnesium and or calcium in drinking water can contribute to reduced cardiovascular disease and other health benefits in populations (WHO 2009). Results of the seasonal variations in the concentration of $\mathrm{Ca}^{2+}$ and $\mathrm{Mg}^{2+}$ versus WHO (2007) standard for drinking water quality across the sampling locations revealed that $\mathrm{Ca}^{2+}$ exceeded the standard limit $(50 \mathrm{mg} / \mathrm{L})$ for drinking water quality at $\mathrm{W} 1, \mathrm{BH} 3$ and W 16 locations for wet season (about 17.65\%) and at W 1, BH 3, BH 4, BH 9 W 16 and W 17 locations in dry season (about 35.29\%). There was a general increase in the concentration of both parameters during the dry season measurement. The concentrations of $\mathrm{K}^{+}$exceeded the WHO (2007) standard limits of (1.0-2.0) at locations BH 2, BH 3, BH 4, BH 5 and BH 6 in the wet season and at $\mathrm{W} 1, \mathrm{BH} 2 \mathrm{BH} 3$, $\mathrm{BH} 4, \mathrm{BH} 5, \mathrm{BH} 6, \mathrm{BH} 8, \mathrm{BH} 9$ and $\mathrm{W} 12$ during the dry season (about 52.94\%), while $\mathrm{Na}^{+}$concentration in all sampled locations during the wet and dry seasons are below the WHO permissible limit of $200 \mathrm{mg} / \mathrm{L}$. About $11.76 \%$ (BH
3 and $\mathrm{W} 17$ ) and $5.88 \%\left(\mathrm{BH} 3\right.$ ) of the measured $\mathrm{Cl}^{-}$values are above the minimum requirement $(250 \mathrm{mg} / \mathrm{L})$ in wet and dry seasons, respectively (Fig. 11). The mean concentration of $\mathrm{Cl}^{-}$increased from 161.58 to $172.1 \mathrm{mg} / \mathrm{L}$ with difference of $10.52(6.5 \%)$. Increase in $\mathrm{Cl}^{-}$level is injurious to people suffering from diseases of heart or kidney (WHO 1997). There is a general decrease in concentration of $\mathrm{Cl}^{-}$in the dry season when compared with measurements obtained during the wet season. This may be attributed to the breaking down of much of the biodegradable mass with time, while the decomposition of the organic components of the waste by the action of microorganisms increases the level of organic matter for the period of the wet season. The measured $\mathrm{SO}_{4}^{2-}$ ion exceeded the prescribed standard limits of $(200 \mathrm{mg} / \mathrm{L})$ set by WHO (2007) in about 17.65\% (BH 3, BH 6, W 12 and $\mathrm{W} 16)$ and $11.76 \%$ (BH 3 and $\mathrm{BH} 5$ ) in dry and wet seasons, while $\mathrm{NO}_{3}^{-}$values in the wet season are all below the minimum requirement $(10 \mathrm{mg} / \mathrm{L})$ set by WHO. About $58.8 \%$ (BH 6, BH 7, BH 8, BH 9, W 10, W 13, W 15, W 16 and $\mathrm{W} 17$ ) of $\mathrm{NO}_{3}^{-}$values in the dry season, however, exceeded the WHO minimum standard (Fig. 12). Sulphate concentrations in groundwater collected around both dumpsites were generally lower than $250 \mathrm{mg} / \mathrm{L}$ limit stipulated by World Health Organization for drinking water. The level of $\mathrm{SO}_{4}^{2-}$, in groundwater under investigation could be traced to geological nature of the soil because interlocation of clays, sands and silt could encourage dissolution of sulphite such as pyrite from interstratified matters percolating water to produce $\mathrm{SO}_{4}^{2-}$, water (Olabaniyi and Owoyemi 2006).

Table 3 presents the Seasonal Paired Samples Statistics of Heavy metal contents of water sample obtained around 
Table 2 Seasonal paired-sample statistics of macroelements and anions content of water samples obtained around the Olusosun dumpsite

\begin{tabular}{|c|c|c|c|c|c|c|c|c|}
\hline Samples & $\mathrm{Ca}(\mathrm{mg} / \mathrm{L})$ & $\mathrm{Mg}(\mathrm{mg} / \mathrm{L})$ & $\mathrm{K}(\mathrm{mg} / \mathrm{L})$ & $\mathrm{Na}(\mathrm{mg} / \mathrm{L})$ & $\mathrm{Cl}^{-}(\mathrm{mg} / \mathrm{L})$ & $\mathrm{SO}_{4}(\mathrm{mg} / \mathrm{L})$ & $\mathrm{PO}_{4}(\mathrm{mg} / \mathrm{L})$ & $\mathrm{NO}_{3}(\mathrm{mg} / \mathrm{L})$ \\
\hline \multirow[t]{2}{*}{ W 1} & 50.10 & 18.20 & 1.34 & 11.28 & 248.15 & 114.0 & 19.6 & 1.7 \\
\hline & 80.16 & 29.12 & 2.46 & 21.90 & 198.5 & 170.0 & 1.08 & 5.10 \\
\hline \multirow[t]{2}{*}{ BH 2} & 20.05 & 10.92 & 2.72 & 9.10 & 124.08 & 93.0 & 21.3 & 8.2 \\
\hline & 32.06 & 11.06 & 3.10 & 15.77 & 106.4 & 12.0 & 0.03 & 9.0 \\
\hline \multirow[t]{2}{*}{ BH 3} & 58.12 & 21.11 & 3.01 & 13.41 & 354.5 & 420.0 & 18.9 & 3.7 \\
\hline & 98.20 & 35.92 & 2.99 & 10.90 & 726.7 & 620.0 & 0.88 & 2.1 \\
\hline \multirow[t]{2}{*}{ BH 4} & 28.06 & 10.19 & 2.01 & 7.61 & 70.9 & 95.0 & 28.9 & 6.3 \\
\hline & 64.13 & 23.30 & 2.01 & 16.65 & 159.5 & 110.0 & 0.63 & 5.0 \\
\hline \multirow[t]{2}{*}{ BH 5} & 36.07 & 13.11 & 4.11 & 5.81 & 106.35 & 60.0 & 30.3 & 0.0 \\
\hline & 38.08 & 13.83 & 3.89 & 9.66 & 124.1 & 290.0 & 0.02 & 9.7 \\
\hline \multirow[t]{2}{*}{ BH 6} & 24.05 & 8.74 & 2.20 & 7.01 & 177.25 & 735.0 & 20.1 & 7.5 \\
\hline & 38.08 & 13.83 & 2.10 & 16.89 & 124.1 & 156.0 & 0.42 & 19.0 \\
\hline \multirow[t]{2}{*}{ BH 7} & 24.06 & 8.74 & 1.04 & 6.20 & 106.35 & 56.0 & 34.4 & 0.2 \\
\hline & 40.08 & 14.56 & 1.10 & 10.99 & 194.8 & 14.0 & 0.02 & 45.8 \\
\hline \multirow[t]{2}{*}{ BH 8} & 30.06 & 10.92 & 1.56 & 4.01 & 124.08 & 61.0 & 15.3 & 1.3 \\
\hline & 30.06 & 10.92 & 2.98 & 15.77 & 88.63 & 4.0 & 0.96 & 15.9 \\
\hline \multirow[t]{2}{*}{ BH 9} & 32.64 & 11.65 & 1.70 & 5.81 & 106.35 & 96.0 & 12.2 & 0.2 \\
\hline & 50.10 & 74.90 & 2.22 & 9.56 & 159.5 & 2.0 & 0.02 & 34.50 \\
\hline \multirow[t]{2}{*}{ W 10} & 18.04 & 6.55 & 1.57 & 11.44 & 159.53 & 33.0 & 9.0 & 9.2 \\
\hline & 42.08 & 15.29 & 1.79 & 14.77 & 70.90 & 14.0 & 0.12 & 26.4 \\
\hline \multirow[t]{2}{*}{ BH 11} & 38.08 & 13.83 & 1.41 & 12.71 & 159.53 & 74.0 & 40.8 & 6.9 \\
\hline & 30.06 & 10.92 & 1.10 & 12.66 & 53.18 & 12.0 & 0.25 & 7.3 \\
\hline \multirow[t]{2}{*}{ W 12} & 28.06 & 10.19 & 1.32 & 10.56 & 106.35 & 572.0 & 16.2 & 1.4 \\
\hline & 34.07 & 12.38 & 2.42 & 10.82 & 70.90 & 28.0 & 0.45 & 26.3 \\
\hline \multirow[t]{2}{*}{ W 13} & 32.50 & 8.34 & 1.68 & 8.52 & 150.43 & 135.0 & 18.5 & 4.6 \\
\hline & 40.10 & 11.50 & 1.76 & 8.45 & 148.23 & 56.7 & 0.43 & 10.5 \\
\hline \multirow[t]{2}{*}{ W 14} & 26.82 & 10.32 & 1.84 & 6.38 & 164.21 & 83.50 & 20.65 & 2.7 \\
\hline & 32.40 & 10.98 & 1.79 & 7.54 & 159.21 & 38.76 & 0.54 & 21.08 \\
\hline \multirow[t]{2}{*}{ W 15} & 40.26 & 9.31 & 1.76 & 7.11 & 122.12 & 56.70 & 32.4 & 5.1 \\
\hline & 39.32 & 8.67 & 1.89 & 8.11 & 130.14 & 37.76 & 0.78 & 16.35 \\
\hline \multirow[t]{2}{*}{ W 16} & 56.5 & 15.32 & 1.63 & 10.56 & 210.68 & 288.56 & 19.78 & 8.7 \\
\hline & 58.34 & 13.78 & 1.60 & 11.54 & 189.56 & 210.23 & 0.67 & 12.38 \\
\hline \multirow[t]{2}{*}{ W 17} & 49.0 & 10.43 & 1.46 & 9.62 & 255.98 & 243.24 & 17.50 & 6.9 \\
\hline & 64.04 & 14.89 & 1.78 & 10.50 & 221.36 & 120.20 & 0.76 & 10.0 \\
\hline \multirow[t]{2}{*}{ Mean } & 34.85 & 11.64 & 1.90 & 8.66 & 161.58 & 189.18 & 22.11 & 4.39 \\
\hline & 47.72 & 19.17 & 2.18 & 12.49 & 172.1 & 111.51 & 0.47 & 16.26 \\
\hline \multirow[t]{2}{*}{ Range } & 18.04-58.12 & $6.55-21.1$ & $1.04-4.11$ & 4.01-13.41 & $70.9-354.5$ & 33-735 & 9-40.8 & 0-9.2 \\
\hline & $30.06-98.2$ & $8.67-74.9$ & $1.1-3.89$ & $7.54-21.9$ & $53.18-726$ & $2-620$ & $.02-1.1$ & $2.1-45$ \\
\hline \multirow[t]{2}{*}{ SD } & 12.27 & 3.71 & 0.76 & 2.71 & 71.25 & 203.59 & 8.42 & 3.22 \\
\hline & 19.28 & 16.06 & 0.73 & 3.88 & 151 & 155.86 & 0.085 & 11.61 \\
\hline \multirow[t]{2}{*}{ Coefficient of variation (\%) } & 35.2 & 31.87 & 40 & 31.29 & 44.09 & 108 & 38.08 & 73.34 \\
\hline & 40.4 & 83.77 & 33.48 & 31.06 & 87.74 & 139.7 & 18.08 & 71.4 \\
\hline WHO/SON standard & 50 & 2.0 & $1.0-2.0$ & 200 & 250 & $200 / 100$ & 5.0 & 10 \\
\hline
\end{tabular}

Bold: August 2014 results (wet season); italic: December 2015 results (dry season)

$B H$ borehole, $W$ well 
Fig. 11 Seasonal variations in $\mathrm{Cl}$ concentration of water sample versus WHO standard around the Olusosun dumpsite
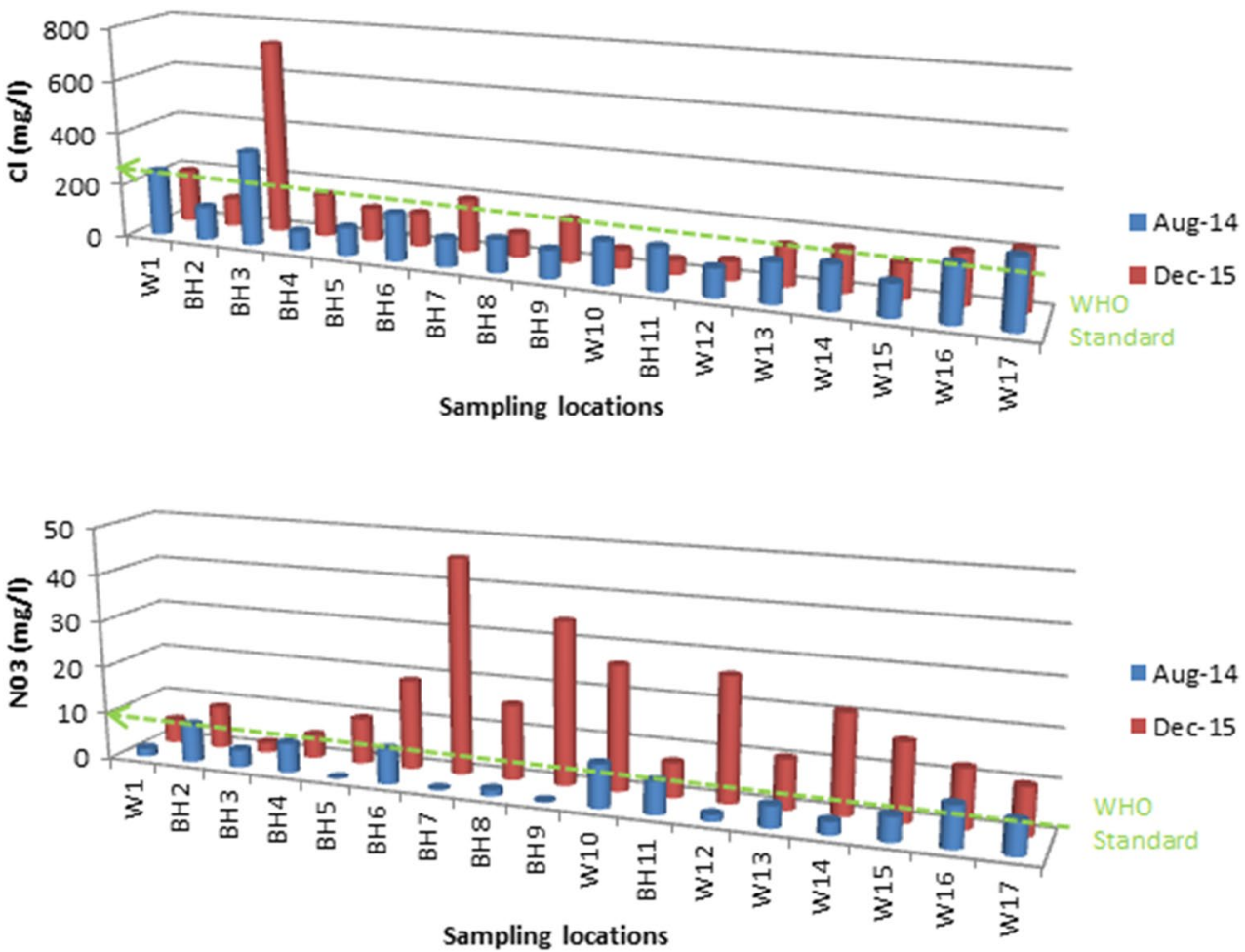

Fig. 12 Seasonal variations in $\mathrm{NO}_{3}$ concentration of water sample versus WHO standard around the Olusosun dumpsite the dumpsite. Among the examined variables, Fe has the highest mean (4.06 mg/L in 2014 and $2.31 \mathrm{mg} / \mathrm{L}$ in 2015), followed by $\mathrm{Zn}(1.35 \mathrm{mg} / \mathrm{L}$ in 2014 and $1.99 \mathrm{mg} / \mathrm{L}$ in 2015) while $\mathrm{Pb}$ and $\mathrm{Ni}$ remained the least $(0.023 \mathrm{mg} / \mathrm{L}$ in 2014 and $0.022 \mathrm{mg} / \mathrm{L}$ in 2015 , and $0.02 \mathrm{mgg} / \mathrm{L}$ in 2014 and $0.009 \mathrm{mg} / \mathrm{L}$ in 2015, respectively). Also, Fe recorded the highest standard deviation $(0.61 \mathrm{mg} / \mathrm{L}$ in 2014 and $2.29 \mathrm{mg} / \mathrm{L}$ in 2015), this is followed by $\mathrm{Zn}(0.48 \mathrm{mg} / \mathrm{L}$ in 2015$)$ and $\mathrm{Mn}(0.38 \mathrm{mg} / \mathrm{L}$ in 2015$)$, while $\mathrm{Ni}$ and $\mathrm{Cr}$ recorded the least values $(0.02 \mathrm{mgg} / \mathrm{L}$ in 2014 and $0.009 \mathrm{mg} / \mathrm{L}$ in 2015 and $0.03 \mathrm{mg} / \mathrm{L}$ in 2014 and $0.038 \mathrm{mg} / \mathrm{L}$ in 2015, respectively). Furthermore, Mn also remains the most absolutely varied parameter among the examined water quality parameters within the study area. On the pattern of relative variation, the result of the coefficient of variation (C.V) shows that all the examined variables are heterogeneous. $\mathrm{Fe}, \mathrm{Mn}$ and $\mathrm{Pb}$ for example top the list with values of $99.13 \%$ in $2015,108.57 \%$ in 2015 and $91.3 \%$ in 2014 , respectively. The WHO permissible level of chromium $(0.05 \mathrm{mg} / \mathrm{L})$ is not exceeded in all the sampled wells in the study area except at BH 8 in 2015, which represents $5.88 \%$ (Table 3). Heavy doses of chromium salts even though are rapidly eliminated from human body could corrode the intestinal tract (WHO 2004). There is $64.7 \%$ increase in $\mathrm{Cr}$ concentration from the dry season results when compared with the wet season. The concentration of Lead did not exceed the WHO permissible limit $(0.01 \mathrm{mg} / \mathrm{L})$ in all the sampled wells except at locations W 1, BH 2, W 13, W 14, W 15 and
$\mathrm{W} 17$ in $2014(35.3 \%)$ and also minimal at BH 6, BH 7, BH9 and W 10 in 2015 (23.5\%). The high concentration of lead detected in the groundwater samples may have originated from used batteries and other lead bearing wastes deposited on the landfill. The WHO permissible level of Copper $(0.5 \mathrm{mg} / \mathrm{L})$ was not exceeded for all samples at the site except at BH 9 in 2014 (about 5.88\%) but was exceeded at locations $\mathrm{BH} 2, \mathrm{BH} 4, \mathrm{BH} 8, \mathrm{BH} 9$ and $\mathrm{BH} 11$ in 2015 which is about $29.4 \%$ of the sampled locations (Table 3 ). The WHO permissible level of iron $(0.3 \mathrm{mg} / \mathrm{L})$ was exceeded in all the sampled borehole water around the study area in the wet season while in the dry season, the permissible limit was not exceeded at locations BH 4, BH 5, W 10, BH 11 and W 12, i.e. about $29.4 \%$ of the locations (Fig. 13). The mean value of Fe reduced from 4.06 to 2.31 with interval difference of 1.75 (75.8\%), with values ranging from 3.06 to 5.01 in August 2014 and 0.06-5.52 in December 2015. Presence of Fe in water can lead to change of colour of groundwater (Rowe et al. 1995). The study further supports the report of high Fe concentrations in groundwater in Nigeria (WHO and UNICEF 2006). The Fe concentration generally decreased in the dry season. This according to Drever (1997) is expected since the solubility of iron minerals in oxygenated waters decrease for increasing $\mathrm{pH}$ values, so at low $\mathrm{pH}$ values, iron concentration should be higher. The WHO permissible level of Zinc $(5.0 \mathrm{mg} / \mathrm{L})$ was not exceeded in sampled groundwater in all the locations at the site from the results obtained during the wet and dry seasons 
Table 3 Seasonal paired-sample statistics of heavy metal contents of water sample obtained around the Olusosun dumpsite

\begin{tabular}{|c|c|c|c|c|c|c|c|}
\hline Samples & $\mathrm{Fe}(\mathrm{mg} / \mathrm{L})$ & $\mathrm{Zn}(\mathrm{mg} / \mathrm{L})$ & $\mathrm{Mn}(\mathrm{mg} / \mathrm{L})$ & $\mathrm{Cu}(\mathrm{mg} / \mathrm{L})$ & $\mathrm{Pb}(\mathrm{mg} / \mathrm{L})$ & Ni (mg/L) & $\mathrm{Cr}(\mathrm{mg} / \mathrm{L})$ \\
\hline \multirow[t]{2}{*}{ W 1} & 3.22 & 1.30 & 1.01 & 0.42 & 0.08 & 0.02 & 0.04 \\
\hline & 3.06 & 2.40 & 0.89 & 0.29 & 0.02 & $N D$ & 0.12 \\
\hline \multirow[t]{2}{*}{ BH 2} & 4.71 & 1.20 & 0.81 & 0.42 & 0.04 & 0.01 & 0.02 \\
\hline & 0.32 & 1.90 & 0.25 & 0.62 & 0.03 & $N D$ & 0.04 \\
\hline \multirow[t]{2}{*}{ BH 3} & 3.81 & 1.01 & 0.70 & 0.40 & 0.01 & 0.02 & 0.03 \\
\hline & 0.34 & 1.20 & 0.41 & 0.34 & 0.03 & $N D$ & 0.04 \\
\hline \multirow[t]{2}{*}{ BH 4} & 5.01 & 1.10 & 0.92 & 0.41 & 0.01 & 0.02 & 0.03 \\
\hline & 0.16 & 1.42 & 0.43 & 0.52 & 0.02 & 0.002 & 0.04 \\
\hline \multirow[t]{2}{*}{ BH 5} & 4.30 & 1.06 & 0.31 & 0.44 & 0.01 & 0.02 & 0.02 \\
\hline & 0.30 & 1.30 & 0.22 & 0.28 & 0.02 & 0.006 & 0.04 \\
\hline \multirow[t]{2}{*}{ BH 6} & 4.20 & 1.91 & 0.67 & 0.40 & 0.01 & 0.03 & 0.02 \\
\hline & 0.46 & 1.67 & 0.42 & 0.44 & 0.007 & 0.01 & 0.04 \\
\hline \multirow[t]{2}{*}{ BH 7} & 3.61 & 1.20 & 0.70 & 0.30 & 0.01 & 0.02 & 0.02 \\
\hline & 5.52 & 2.42 & 0.09 & 0.29 & 0.005 & 0.008 & 0.01 \\
\hline \multirow[t]{2}{*}{ BH 8} & 3.06 & 1.22 & 0.21 & 0.39 & 0.01 & 0.03 & 0.03 \\
\hline & 3.80 & 2.70 & 0.09 & 0.53 & 0.013 & 0.002 & 0.07 \\
\hline \multirow[t]{2}{*}{ BH 9} & 3.60 & 1.25 & 0.44 & 0.51 & 0.01 & 0.01 & 0.03 \\
\hline & 4.92 & 2.04 & 0.03 & 0.51 & 0.007 & 0.01 & 0.02 \\
\hline \multirow[t]{2}{*}{ W 10} & 3.40 & 1.03 & 0.57 & 0.34 & ND & 0.02 & 0.02 \\
\hline & 0.20 & 2.13 & 0.09 & 0.34 & 0.01 & $N D$ & 0.02 \\
\hline \multirow[t]{2}{*}{ BH 11} & 3.55 & 1.20 & 0.50 & 0.27 & ND & 0.01 & 0.02 \\
\hline & 0.12 & 2.67 & 0.07 & 0.55 & 0.03 & $N D$ & 0.03 \\
\hline \multirow[t]{2}{*}{ W 12} & 4.10 & 2.11 & 0.512 & 0.26 & 0.01 & 0.02 & 0.03 \\
\hline & 0.06 & 2.55 & 0.043 & 0.43 & 0.02 & $N D$ & 0.02 \\
\hline \multirow[t]{2}{*}{ W 13} & 4.31 & 1.25 & 0.55 & 0.34 & 0.02 & 0.01 & 0.03 \\
\hline & 0.50 & 2.02 & 0.21 & 0.47 & 0.03 & 0.01 & 0.03 \\
\hline \multirow[t]{2}{*}{ W 14} & 3.85 & 2.01 & 0.63 & 0.40 & 0.04 & 0.02 & 0.02 \\
\hline & 4.85 & 2.04 & 0.34 & 0.44 & 0.03 & $N D$ & 0.04 \\
\hline \multirow[t]{2}{*}{ W 15} & 4.55 & 1.34 & 1.05 & 0.45 & 0.05 & 0.02 & 0.03 \\
\hline & 4.65 & 1.31 & 1.35 & 0.25 & 0.04 & 0.01 & 0.04 \\
\hline \multirow[t]{2}{*}{ W 16} & 4.78 & 1.30 & 0.82 & 0.39 & 0.01 & 0.03 & 0.04 \\
\hline & 5.51 & 2.00 & 0.98 & 0.40 & 0.03 & 0.02 & 0.03 \\
\hline \multirow[t]{2}{*}{ W 17} & 5.00 & 1.38 & 0.56 & 0.38 & 0.02 & 0.01 & 0.02 \\
\hline & 4.54 & 2.05 & 0.08 & 0.40 & 0.03 & 0.01 & 0.03 \\
\hline \multirow[t]{2}{*}{ Mean } & 4.06 & 1.35 & 0.64 & 0.38 & 0.023 & 0.02 & 0.03 \\
\hline & 2.31 & 1.99 & 0.35 & 0.42 & 0.022 & 0.009 & 0.038 \\
\hline \multirow[t]{2}{*}{ Range } & $3.06-5.01$ & $1.01-2.11$ & $0.21-1.05$ & $0.26-0.51$ & 0.01-0.08 & $0.01-0.03$ & 0.02-0.04 \\
\hline & $0.06-5.52$ & $1.2-2.7$ & $0.03-1.35$ & $0.25-0.62$ & $0.005-0.04$ & $0.002-0.02$ & $0.01-0.12$ \\
\hline \multirow[t]{2}{*}{ SD } & 0.61 & 0.34 & 0.23 & 0.07 & 0.021 & 0.007 & 0.007 \\
\hline & 2.29 & 0.48 & 0.38 & 0.12 & 0.01 & 0.005 & 0.025 \\
\hline \multirow[t]{2}{*}{ Coef. of variation (\%) } & 15.02 & 25.18 & 35.94 & 18.42 & 91.3 & 35 & 23.33 \\
\hline & 99.13 & 24.1 & 108.57 & 28.57 & 45.45 & 55.5 & 65.78 \\
\hline WHO/SON standard & 0.3 & 5.0 & 0.5 & 0.5 & 0.01 & 0.02 & 0.05 \\
\hline
\end{tabular}

Bold: August 2014 results (wet season); italic: December 2015 results (dry season)

$B H$ borehole, $W$ well, $N D$ not detected

(Fig. 14). Therefore, zinc concentrations in groundwater around this area did not present any drinking water concerns. The WHO permissible limit for manganese
$(0.5 \mathrm{mg} / \mathrm{L})$ is exceeded in all the borehole samples in the study area except at locations $\mathrm{BH} 5, \mathrm{BH} 8, \mathrm{BH} 9$, and $\mathrm{BH} 11$ from the wet season results, while the dry season 
Fig. 13 Seasonal variations in Fe concentration of water sample versus WHO standard around the Olusosun dumpsite

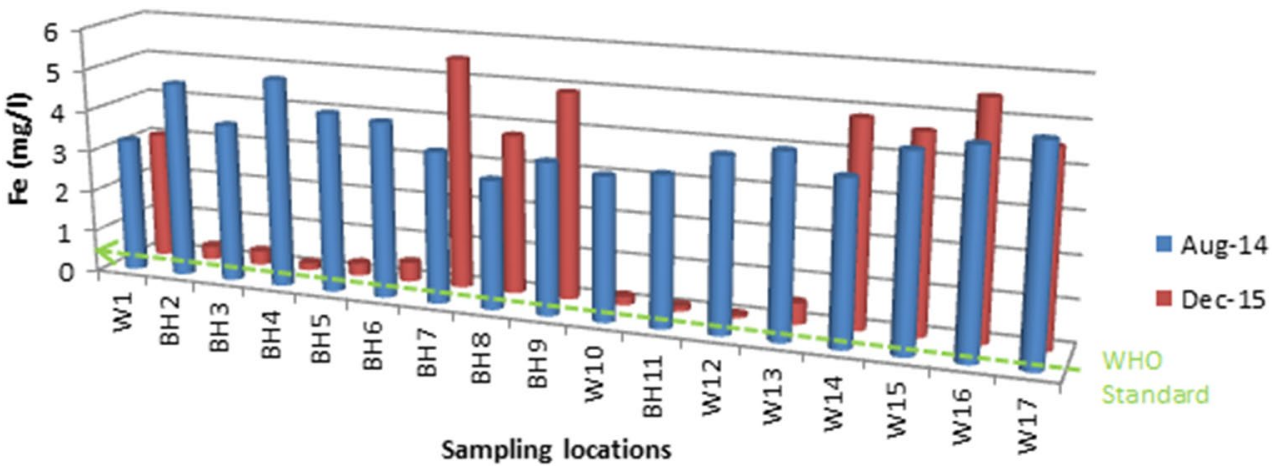

Fig. 14 Seasonal variations in $\mathrm{Zn}$ concentration of water sample versus WHO standard around the Olusosun dumpsite
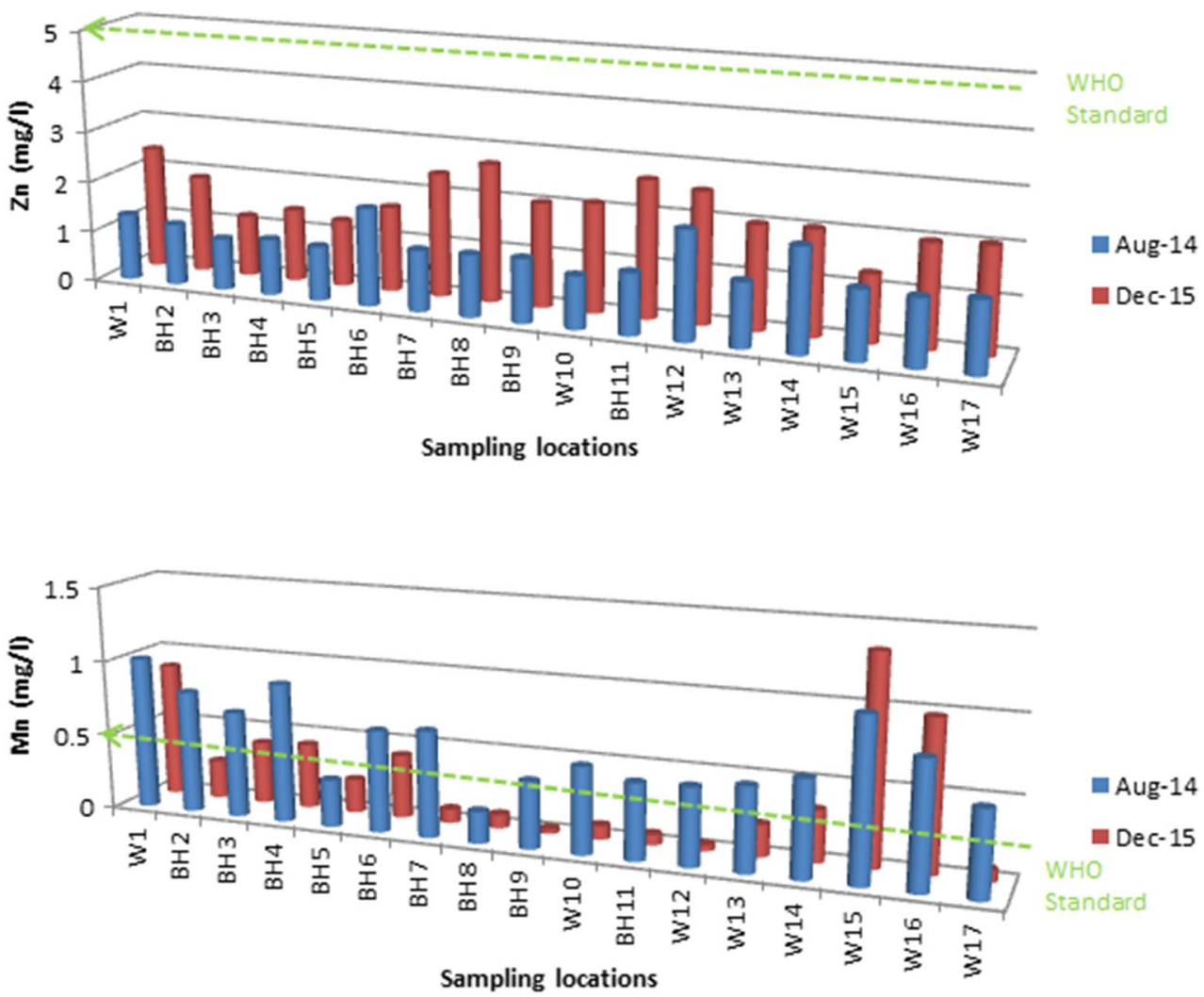

Sampling locations
Fig. 15 Seasonal variations in Mn concentration of water sample versus WHO standard around the Olusosun dumpsite samples show that Mn concentration was exceeded at W 1, W 15 and W 16 locations i.e. about 17.65\% (Fig. 15). Concentrations of manganese in excess of $0.2 \mathrm{mg} / \mathrm{L}$ make water distasteful to drinking with no specific toxic effects (Longe and Enekwechi 2007).

\section{Conclusion}

Analysis of VES data from previous investigations and 2D resistivity models obtained from this study show that there is a progressive increase in the depth of migration of the contaminants generated on this dumpsite into the subsurface environment over the years. Comparing the wet and dry season results, there is generally an increase in the mean concentrations of TDS, EC, temperature, hardness and most of the chemical parameters measured from the dry season study for all the sampled locations when compared with the wet season. This could be could be attributed to the increase in concentration of the dissolved metals due to evaporation, and on the other hand, dilution effect of the rainfall during the wet season. The implication is that the water around the study area has lower quality in the dry season. Based on the results of geophysical survey conducted around the dumpsite during this study, it is recommended that in exploring groundwater around this area, deeper aquifers should be targeted in order to access clean water and water treatment should be given more priority during the dry season before 
consumption and usage for other domestic purposes to avoid waterborne diseases.

Acknowledgements The authors are thankful to Covenant University for the financial support and also to Lagos Waste Management Authority for the permission to use their dumpsite for this study.

Open Access This article is distributed under the terms of the Creative Commons Attribution 4.0 International License (http://creativeco mmons.org/licenses/by/4.0/), which permits unrestricted use, distribution, and reproduction in any medium, provided you give appropriate credit to the original author(s) and the source, provide a link to the Creative Commons license, and indicate if changes were made.

\section{References}

Abdulrafiu OM, Adebola AA, Oladele O (2016) Vulnerability assessment of groundwater pollution in the vicinity of an active dumpsite (Olusosun), Lagos, Nigeria. Chem Int 2(4):232-241

Adeyi AA, Majolagbe AO (2014) Assessment of groundwater quality around two major active dumpsites in Lagos, Nigeria. Glob J Sci Front Res 14(7):2249-4626

Agagu OK (1985). A geological guide to bituminous sediments in Southwestern Nigeria, (unpubl monograph). Department of Geology, University of Ibadan

AGI (2003) Earth imager 2D resistivity inversion software, version 1.5.10. Advanced Geosciences, Inc, Austin

APHA (2005) Standard methods the examination of water and wastewater, 23rd edn. American Public Health Association, Washington D.C

Ayolabi EA (2005) Geoelectric evaluation of Olushosun landfill site, southwest Nigeria and its implications on groundwater. J Geol Soc India 66:318-322

Ayolabi EA, Lucas OB, Chidinma ID (2014) Integrated geophysical and physicochemical assessment of Olushosun sanitary landfill site, southwest Nigeria. Arab J Geosci. https://doi.org/10.1007/ s12517-014-1486-8

Bably P, Kumari S (2000) Heavy metal pollution index of groundwater of an abandoned open cast mine with fly ash: a case study. Mine Water Environ 27:265-267

Drever NA (1997) The geochemistry of natural waters. Surface and groundwater environments, 3rd edn. Prentice-Hall Inc, Englewood Cliffs, pp 670-677

Enu EI (1990) Nature and occurrence of tar sands in Nigeria. In: Ako BD, Enu EI (eds) Occurrence, utilization and economics of tar sands. Nigeria Mining and Geosciences Society publication on tar sands workshop. Olabisi Onabanjo University, Ago-Iwoye, pp 11-16

Jones HA, Hockey RD (1964) The geology of part of south-western Nigeria. Geol Surv Niger Bull 31:1-101

Lake B (2000) Understanding soil pH. Acid Soil Action: An iniciative of NSW Government. http://www.dpi.nsw.gov.au/_data/assets/ pdf_file/0003/167187/soil-ph.pdf. Accessed 08 Oct 2016

LAWMA (2004) Landfill gates records. Ijora Head office, Ijora, Lagos

Loke MH, Barker RD (1996) Rapid least-squares inversion of apparent resistivity pseudosection by quasi-Newton method. Geophys Prospect 44:131-152
Longe EO, Enekwechi LO (2007) Investigation on potential groundwater impacts and influence of local hydrogeology on natural attenuation of leachate at a municipal landfill. Int J Environ Sci Technol 4(1):133-140

Mondelli G (2004) Investigação geoambiental em áreas de disposição de Resíduos Sólidos Urbanos utilizando a técnica do piezocone. M.Sc. thesis, USP, São Paulo, Brazil, p 391

NSDQW (2007) Nigerian standard for drinking water quality. Nigerian Industrial Standard NIS 554. Standard Organization of Nigeria, Lagos

Nton ME (2001) Sedimentological and geochemical studies of rock units in the eastern Dahomey Basin, south western Nigeria. Unpublished Ph.D. thesis, University of Ibadan, p 315

Olabaniyi SB, Owoyemi FB (2006) Characterization by factor analysis of the chemical facies of groundwater in the Deltaic plain Sands Aquifer of Warri, Niger Delta, Nigeria. AJST Sci Eng Ser 2 7(1):73-81

Omatsola ME, Adegoke OS (1981) Tectonic evolution and cretaceous stratigraphy of Dahomey Basin. J Min Geol 18:130-137

Oyeku OT, Eludoyin AO (2010) Heavy metal contamination of groundwater resources in a Nigerian urban settlement. Afr J Environ Sci Technol 4(4):201-214

Rowe RK, Quigley RQ, Booker JR (1995) Clay barrier systems for waste disposal facilities. E and FN Spon, London

Soupios P, Papadopoulos N, Papadopoulos I, Kouli M, Vallianatos F, Sarris A, Manios T (2007) Application of integrated methods in mapping waste disposal areas. Environ Geol 53:661-675

Subramani T, Elango L, Damodarasamy SR (2005) Groundwater quality and its suitability for drinking and agricultural use in Chithar River Basin, Tamil Nadu, India. Environ Geol 47:1099-1110

United States Environmental Protection Agency (2013) Drinking Water Contaminants. http://water.epa.gov/drink/contaminants/index .cfm. Accessed 3 June 2013

WHO (1997) Guidelines for drinking-water quality, volume 3: surveillance and control of community supplies, 2nd edn. WHO, Geneva. www.who.int/water_sanitation_health. Accessed 12 Aug 2015

WHO (2004) Guidelines for drinking-water quality, volume 1: recommendations, 3rd edn. WHO, Geneva. www.who.int/water_sanit ation_health. Accessed 6 July 2010

WHO (2007) Water for pharmaceutical use in quality assurance of pharmaceuticals. A compendium of guidelines and related materials, 2nd updated edn. World Health Organization, Geneva, pp $170-187$

WHO/UNICEF (2006) Core questions on drinking-water, sanitation and hygiene for household surveys. WHO and UNICEF, Geneva

WHO (2009) Calcium and magnesium in drinking water: public health significance. World Health Organization press, Spain, p 194. http://whqlibdoc.who.int/publications/2009/9789241563550en g.pdf

Publisher's Note Springer Nature remains neutral with regard to jurisdictional claims in published maps and institutional affiliations. 